\title{
Experimental labor markets and policy considerations: incomplete contracts and macroeconomic aspects
}

Citation for published version (APA):

Casoria, F., \& Riedl, A. M. (2012). Experimental labor markets and policy considerations: incomplete contracts and macroeconomic aspects. METEOR, Maastricht University School of Business and Economics. METEOR Research Memorandum No. 057 https://doi.org/10.26481/umamet.2012057

Document status and date:

Published: 01/01/2012

DOI:

10.26481/umamet.2012057

Document Version:

Publisher's PDF, also known as Version of record

\section{Please check the document version of this publication:}

- A submitted manuscript is the version of the article upon submission and before peer-review. There can be important differences between the submitted version and the official published version of record.

People interested in the research are advised to contact the author for the final version of the publication, or visit the DOI to the publisher's website.

- The final author version and the galley proof are versions of the publication after peer review.

- The final published version features the final layout of the paper including the volume, issue and page numbers.

Link to publication

\footnotetext{
General rights rights.

- You may freely distribute the URL identifying the publication in the public portal. please follow below link for the End User Agreement:

www.umlib.nl/taverne-license

Take down policy

If you believe that this document breaches copyright please contact us at:

repository@maastrichtuniversity.nl

providing details and we will investigate your claim.
}

Copyright and moral rights for the publications made accessible in the public portal are retained by the authors and/or other copyright owners and it is a condition of accessing publications that users recognise and abide by the legal requirements associated with these

- Users may download and print one copy of any publication from the public portal for the purpose of private study or research.

- You may not further distribute the material or use it for any profit-making activity or commercial gain

If the publication is distributed under the terms of Article $25 \mathrm{fa}$ of the Dutch Copyright Act, indicated by the "Taverne" license above, 
Fortuna Casoria, Arno Riedl

Experimental labor markets and policy considerations: I ncomplete contracts and macroeconomic aspects

$\mathrm{RM} / 12 / 057$

\section{METEOR}

Maastricht University school of Business and Economics

Maastricht Research School of Economics

of Technology and Organization

\section{PO. Box 616}

NL - 6200 MD Maastricht

The Netherlands 


\title{
Experimental labor markets and policy considerations: Incomplete contracts and macroeconomic aspects
}

October 2012

Fortuna Casoria*

Arno Riedl**

\begin{abstract}
This survey focuses on experimental labor markets investigating two aspects that deem us important for a better understanding of labor market relations and the consequences for labor market policies. The first part of the survey is dedicated to papers that assess the prevalence of reciprocal considerations in incomplete labor contracts. The second part summarizes the relatively small but growing experimental literature exploring labor issues in a macroeconomics and public finance setting and studying the interaction between taxation and labor market outcomes.
\end{abstract}

Keywords: laboratory experiment, labor markets, incomplete contracts, giftexchange, labor market policy

\footnotetext{
* Department of Economics (AE1), Maastricht University, P.O. Box 616, 6200 MD Maastricht, The Netherlands; e-mail: f.casoria@maastrichtuniversity.nl

${ }^{* *}$ CESifo, IZA, Department of Economics (AE1), Maastricht University, P.O. Box 616, 6200 MD

Maastricht, The Netherlands; e-mail: a.riedl@maastrichtuniversity.nl
} 


\section{Introduction}

Experimental economics focus on the functioning of labor markets has been growing over the years and the advantages of applying experimental methods to labor economics have been extensively discussed (see, e.g., Fehr, Goette, and Zehnder 2009, Charness and Kuhn 2011). Experiments allow for tight control over the several environmental factors that can affect individual behavior, and render causal relations easier to infer. The possibility of controlling these factors implies the possibility of varying them and studying whether and to what degree the enforced changes affect decisions. This feature seems to be particularly suitable to analyze labor markets, where a large amount of labor-related available data are circumstantial, implying that it becomes difficult to exactly discern which factors play which role in the realization of a given outcome.

The experimental labor economics literature is quite vast with a wide range of issues addressed and this survey does not intend or pretend to cover the experimental labor literature in all its breath. We rather focus on two aspects that we deem important for a better understanding of labor market relations and the consequences for labor market policies. More specifically, the first part of the survey is dedicated to papers that assess the prevalence of reciprocal considerations in incomplete labor contracts. The second part summarizes the relatively small but growing experimental literature exploring labor issues in a macroeconomics and public finance setting and studying the interaction between taxation and labor market outcomes. Readers interested in other aspects explored in experimental labor economics and, especially, principal-agent relationships, such as work incentives or multi-task problems, arbitration, job search or gender differentials, which are referred to the excellent review of Charness and Kuhn (2011) and Fehr, Goette, and Zehnder (2009).

In this survey, first, our attention goes to incomplete labor markets. Labor relations are often contractually incomplete in the sense that effort is typically not (fully) contractible or enforceable by a third party. This feature leaves room for reciprocal motivations to play a role in the work process as workers' general job attitudes become important (Fehr and Falk 1999). The gift-exchange game, first implemented and introduced into the literature by Fehr, Kirchsteiger and Riedl (1993), was designed to mimic precisely this situation. It tests the so-called gift exchange hypothesis of efficiency wage theory (Akerlof 1982; Akerlof and Yellen 1988, 1990), according to 
which, and in contrast to standard theory, there is a positive relationship between the wages offered by firms and the effort exerted by workers. In a gift-exchange market wage offers are binding, while workers can discretionarily choose the amount of effort to exert. Experimental evidence has shown that a positive relation between wages and effort indeed emerges in such markets. While we provide a survey of the main results related to the existence of this positive wage-effort relation we also focus on those studies that have tried to assess the implication of these findings for policy making. In addition, the robustness of the positive wage-effort relation is surveyed showing that while it survives many institutional variations and experimental conditions, there are also environmental factors under which gift-exchange has difficulties to emerge.

The possibility of using laboratory experiments to better understand the functioning of markets has been mostly explored to study causal relationships at a micro level. However, lab experiments can also be a valuable research tool for gaining insights into the effects of alternative labor policies or institutions at a macro level. Indeed, the main strengths of the experimental method, control and replication, can be very useful in the domain of macroeconomics which traditionally relies on circumstantial field data which may suffer from data non-availability, endogeneity or measurement error. This implies that the casual impact of a given variable, e.g. an increase of a labor tax, on the economic performance becomes difficult to be assessed. Experimental labor economics in macroeconomics context can be useful here and help overcome some of these problems. The second part of this survey focuses on the small but growing literature of laboratory labor market experiments in a macroeconomics and public finance context.

The remainder of the paper is organized as follows. Section 2 surveys the interaction between contractual incompleteness and gift-exchange and is subdivided into an introductory section describing the common features of most of the studies. Thereafter, some fundamental results are reviewed followed by a section discussing the interaction between gift-exchange and explored labor market institutions and policies. At the end studies investigating the robustness of the gift-exchange relationship are reviewed. Section 3 surveys labor market experiments in a macroeconomics and public finance context. Finally, Section 4 concludes and outlines suggestions for future research. 


\section{Experimental gift exchange labor markets}

\subsection{Common features across experiments}

Many of the experiments described in this section ground on a similar basic frame of the gift-exchange game. At the beginning of the experimental session, subjects are randomly assigned the roles of either firms or workers, and they keep their role during the whole session. In the first stage, firms offer a contract specifying the wage. In some version workers have to accept what is offered while in others the contract may be rejected in favor of some outside option. In the second stage, workers decide on the level of effort they want to exert, which is costly to them but profitable to the firm. Mostly (but not always) this two-stage game repeated for several periods with the same or changing firm-worker pairs. For the first stage, the wage formation process, commonly one of three institutions is explored: bilateral bargaining, one-sided auction or double auction markets.

In bilateral bargaining, a firm is exogenously and randomly matched with a worker either only at the beginning of the experiment or at the beginning of each period. In each period, a firm proposes a wage only to the worker with whom it has been matched.

In one-sided auction markets, firms publicly announce their wage offers, which can be accepted by any worker. Firms are allowed to revise their (non-accepted) offers according to an improvement rule, so that the new offers must be higher than any existing wage offer. Workers cannot make counteroffers. In double auction markets, both, firms and workers, can submit and accept wage offers at any time during the trading period. In both market institutions, after a wage contract is concluded the involved firm and the worker are removed from the market for that trading period. Hence, in contrast to bilateral bargaining, the matching process is endogenous and occurs through the acceptance of a wage proposal. Firms and workers who do not strike a contract receive some reservation earnings. In the most common implementation, at most one contract per period can be concluded and often there is an excess supply of labor.

In the basic implementation of the second stage, the worker's costly effort choice, firms can neither punish nor reward workers for their choice. Further all institutional 
features are public knowledge, including the number of firms, workers, and periods, the matching mechanism, the feasible effort levels, the costs of effort, the wage range, and the payoff functions. Wage offers may be public or private depending on the chosen market institution, but a worker's effort choice is always private information, in the sense that it is only revealed to the firm with which the worker has concluded a contract. Identities of trading partners are usually not revealed.

\section{Effort levels and cost function}

Most studies reviewed here adopt one of two effort-cost schedules. In one version costs $c(e)$ are increasing and convex in effort $e$ as, e.g., in Table 1, and in another common version costs are linear in effort.

Table 1: Effort levels and costs of effort

\begin{tabular}{lcccccccccc}
\hline Effort $e$ & 0.1 & 0.2 & 0.3 & 0.4 & 0.5 & 0.6 & 0.7 & 0.8 & 0.9 & 1 \\
Cost $c(e)$ & 0 & 1 & 2 & 4 & 6 & 8 & 10 & 12 & 15 & 18 \\
\hline
\end{tabular}

\section{Payoff functions}

Also regarding the payoff functions for firms and workers there are two commonly implemented versions. Firms' payoff function is often a version of

$$
\pi^{F}=(v-w) e+k
$$

or

$$
\pi^{F}=v-w+k
$$

where $v$ denotes an exogenously given redemption value, $w$ the wage, $e$ the effort chosen by the worker, and $k$ some lump-sum transfer..

Workers' payoff function is basically always implemented as the difference between the accepted wage, $w$, the incurred effort cost, $c(e)$, and some fixed costs or transfer $c_{0}$ :

$$
\pi^{W}=w-c(e)-c_{0}
$$

The parameter values are chosen such that under the assumption of material selfinterest workers will never choose an effort level higher than the minimum effort, irrespective of the accepted wage. Rational and materially selfish firms will anticipate this and, hence, offer the lowest positive wage satisfying workers' participation constraint. The predicted outcome is thus low wages, low efforts, and most importantly no positive relationship between wages and effort levels. Alternatively, the gift- 
exchange hypothesis (Akerlof 1982), postulates a positive correlation between wages offered and effort provided and, in consequence, higher than minimum wages and higher than minimum effort levels. ${ }^{1}$

\subsection{Fundamental results}

This section reviews some of the seminal experimental gift-exchange labor markets and summarizes now well-established empirical results on the wage-effort relation emerging in markets characterized by contractual incompleteness regarding workers' effort. First, early experiments are presented, where the gift-exchange hypothesis is tested in oneshot encounters. In these experiments firms and workers meet essentially only once leaving no or little room for reputation concerns. Next, we survey papers where reputation may play a role due to repeated interactions between the same firm-worker pair. Finally, we present evidence on the role of negative reciprocity and wage attribution on the functioning of gift-exchange labor markets.

\section{Gift-exchange in one-shot interactions}

Evidence on the presence of gift-exchange in experimental labor markets dates back to the experiment implemented by Fehr, Kirchsteiger and Riedl (1993) who have been the first to use the above described set-up to test for the validity of the fair wage-effort hypothesis. They model the labor market as a one-sided auction and frame it in good market terms, with a language that involves buyers and sellers who choose prices and quality. The authors observe clear evidence in favor of the gift-exchange hypothesis as wages and effort are clearly above their respective minimum level and also do not show any tendency to decline over periods. Additionally, wage and effort are strongly positively correlated, with higher wages being reciprocated by higher effort levels.

In a second paper, Fehr, Kirchsteiger and Riedl (1998) check whether observed high wages are due to firms' unconditional preference to pay high wages or whether it is because of workers' willingness to reciprocate high wages with high effort levels. They compare two different treatments (reciprocity treatment and control treatment) which

\footnotetext{
${ }^{1}$ The gift-exchange wage-effort relationship can be rationalized by assuming outcome based social preferences (e.g., Fehr and Schmidt 1999, Bolton and Ockenfels 2000), intention-based reciprocal motives (Rabin 1993, Dufwenberg and Kirchsteiger 2004), and a mixture of both (Levine 1998, Falk and Fischbacher 2006).
} 
differ only in that in the control treatment effort levels are exogenously fixed at the lowest effort level, eliminating opportunities for gift-exchange, whereas in the reciprocity treatment, workers are free in their effort choices. Since subjects participated in both treatments it could be tested if the same firms change behavior or not. What is found is that very same firms which pay rather high wages when workers can reciprocate lower their offers when the effort is fixed by the experimenter. This shows that it is (to a large extent) not firms unconditional preference to pay high wages but that they are induced by experienced and anticipated low effort responses to low wages, which in turn would lower firms' profits.

Fehr, Kirchler, Weichbold, and Gächter (1998) are the first to study the effect of the competition among workers on wages. To this purpose, they conduct three different treatments: a one-sided auction, which they call gift-exchange market (henceforth GEM), a bilateral gift-exchange (BGE) and a complete contract market (CCM). The CCM and the GEM are identical to each other, except for the fact that in the CCM the maximum effort level is exogenously enforced. By comparing the wages in these two markets it could be assessed whether the high wages in the GEM as found by Fehr, Kirchsteiger, and Riedl $(1993,1998)$ are indeed attributable to gift-exchange. In BGE firms and workers are exogenously matched, so that competition in the labor market cannot play any role. Hence, comparing the wages in the BGE with those in the GEM helps understand to what extent competition affects wage levels.

The authors find that high wages are reciprocated by high efforts both in GEM and BGE, with no tendency for this positive correlation to decline over time. Importantly, already after a few periods wages in GEM and BGE coincide, indicating that labor market competition has no effect on wage formation. However, wages in GEM are significantly above wages in CCM, where firms constantly try to enforce lower wages. This suggests that firms anticipate workers' reciprocal responses and that the payment of noncompetitive wages generates higher profits. In consequence, firms are unwilling to enforce low wages when there is room for workers to reciprocate with effort.

\section{Gift-exchange and reputation}

Employment relationships are seldom characterized by one-shot transactions, rather employers and employees often interact repeatedly over time, which creates incentives 
for even for materially selfish workers to be act reciprocally, if they can expect (future) material gains from it. This potential reputation effect has been explored in Gächter and Falk (2002). In their experiment they compare behavior in a one-shot (OS) treatment two that in a repeated game $(R G)$ treatment, where the same firm-worker pairs interact repeatedly.

In line with other findings, they find that taken across all periods, both average wages and effort levels exceed the minimal values. Importantly, what they also find is that for similar wages in the two treatments, workers' are more reciprocal in their effort choices in $\mathrm{RG}$ than in OS: This shows that repeated interaction and reputation incentives strengthen the positive wage-effort relation. An individual level analysis further suggests that selfish subjects have a strong incentive to imitate reciprocity because providing high effort in response to high wage offers helps their reputation and gives them access to attractive wage offers. Hence, the repetition disciplines (at least some of) the selfish individuals.

Brown, Falk and Fehr (2004) implement three treatment conditions in order to investigate how contractual incompleteness affects the nature of market interactions and the formation of relational contracts. In all treatments, the market for contracts is organized as a one-sided auction where contracts consist of a wage, a desired effort level, and the firm's ID number. In the complete contracts treatment (C), a firm's desired effort level is exogenously enforced by the experimenter. Under the incomplete contract condition (ICF), the worker can choose any effort in the feasible range. In both these treatments, firms and workers have fixed ID numbers throughout the whole experimental session, which allows for repeated interactions with the same trader. That is, a firm can address its contract offer to a specific worker in consecutive periods. In the third treatment (ICR), firms and workers are randomly assigned a new ID number in each period, ruling out the possibility for them to enter long-term relations. In each trading period firms can make private or public offers, where private offers are only transmitted to the worker with whom a firm wants to trade while public offers can be seen and accepted by any worker in the market.

The authors find that, under complete contracts, traders are indifferent to their trading partners' identities, whereas firms strongly prefer to trade with the same worker over many consecutive periods, when third party enforcement is ruled out. In the former 
case, contract offers are mostly public offers and the majority of trades take place in one-shot transactions. In contrast, under the incomplete contract condition, trades are usually privately initiated and bilateral relationships emerge.

In the $\mathrm{C}$ treatment, firms pay relatively low wages and appropriate the largest share of the gains from trade; whereas in ICF they pay high wages and earnings from trade are distributed rather equally. Effort is significantly higher in ICF, while in the treatment where the possibility of contract renewals is removed, average effort drops and workers choose the minimal effort level in most cases. An important insight from this paper is that firms use high wages, together with the threat of firing, to discipline selfish workers. They adopt a policy of contingent contract renewal where relatively high effort levels are rewarded with a new contract, while relations with workers providing low effort are terminated with high probability.

\section{Gift exchange, negative reciprocity and wage attribution}

Some of the results survived above have been criticized because they are obtained in an environment that may favor workers' opportunity to exhibit positive reciprocity, that is by responding to high wages with high effort levels. However, negative reciprocity, the willingness to incur costs to punish unkind actions, may also have a role in the wage formation with potential opposite effects. As low effort responses to low wages may unravel into even lower wages and efforts.

To study the role of negative reciprocity, Fehr and Falk (1999) compare double auction labor markets where effort is endogenous (main treatment) to others where effort is exogenously fixed (control treatment), with excess supply of workers in both cases. What distinguishes this experiment is the implementation of a modified cost function, according to which a selfish money-maximizing worker should always choose the maximum effort level, because lower levels are more costly. Although, overall the positive wage-effort relation is still present, results from the main treatment show that workers indeed react to low wage offers by choosing non-maximal effort levels. This negatively reciprocal behavior leads firms to pay higher wages in the main treatment, even if workers underbid each other's wage offers. In contrast, in the control treatment wages tend to decrease over time and to come close to the competitive equilibrium level. These findings show that firms may be reluctant to push wages down towards the 
competitive level, if workers have the opportunity to punish them via their effort choices. Workers' negative reciprocity has a remarkable impact on wage levels as it generates wages that are downwardly rigid.

Charness (2004) explores bilateral gift-exchange under three experimental conditions that differ in the wage-generating mechanism. First, wages are determined by the firm, second they are generated by a draw from a bingo cage, and, third, by an assignment by a third party, the experimenter. In all cases, workers are informed whether the received wage has been assigned by either the firm or one of the external processes. In all treatments, there is a positive relationship between wages and effort levels. However, at low wages, the effort level is lower when the wage is chosen by a firm than when it is exogenously generated, suggesting the presence of negative reciprocity. That is, workers never provide costly effort when a low wage can be attributed to the firm's intention but do so when the low wage comes from an exogenous source. At high wage levels, there is essentially no difference in effort levels across treatments.

Pereira, Silva and Silva, J.A. (2006) compare a standard gift-exchange treatment (GET) with a gift/offense-exchange treatment (GOET), where workers have the possibility of reciprocating either positively or negatively. In their specification, the GOET is characterized by some asymmetry with higher marginal costs when responding positively to a wage than when responding negatively. The reported results from the GET are in line with those in the literature. In the GOET, interestingly, a larger number of workers choose effort levels close to the materially selfish prediction even for wages that are clearly above the minimum wage. This may point to some framing effect as observed in dictator allocation experiments (Bardsley 2008, List 2007). Importantly, also in GOET a significant fraction of workers show either positive or negative reciprocal behavior.

The results from Charness (2004) suggest that the mechanism according to which wages are formed has a non-negligible impact on workers' performances. Maximiano, Sloof and Sonnemans (2013) go an important step in this direction and study the wage attribution issue by means of a more complex gift-exchange environment, where ownership and control are separated. Specifically, owners do not directly set a worker's wage and the manager, who actually determines the wage, does not bear the full wage costs and does also not fully benefit from workers' higher efforts. 
The authors consider four treatments. The bilateral condition $(\mathrm{BC})$ is a standard bilateral gift-exchange setting, with a firm consisting of a single owner-manager who is directly responsible for choosing the worker's wage. In the two trilateral conditions (TC0 and TC25), the firm is owned by a shareholder, who claims most of the firm's profit, but controlled by a manager, who chooses the worker's wage. In TC0 the manager is paid a fixed wage and in TC25 condition the manager earns 25 percent of the firm's profit. In the fourth treatment, wages are randomly determined by the experimenter (as in Charness (2004)). This last condition is used for checking whether control per se is important for the gift-exchange relationship or workers only care about the fact that wages are paid by the firm.

In all treatments, a gift-exchange wage-effort relationship is found. The higher the wage offered, the higher the average effort level chosen by workers, irrespective of the firm's composition and whether the manager receives part of the profits or not. Importantly, the wage-effort relationship is steepest when wages are determined by a member of the firm. The finding that the wage-effort relationship does not differ among the three endogenous treatments indicates that workers are not particularly sensitive to how ownership and control are divided within the firm, but is reciprocal towards the firm as a whole.

\subsection{Gift-exchange labor markets and policy instruments}

Despite the robustness and prevalence of gift-exchange wage-effort relationships still relatively few experimental studies investigate policy implications of it. Among others, questions that could be asked are: Are (un)employment policies similarly (in)effective in gift-exchange and complete contract markets? Do optimal and redistributive tax

policies have the predicted effects in gift-exchange labor markets? Here we survey a handful of experimental studies asking such important policy implications of the giftexchange in labor markets.

\section{Taxation}

Riedl and Tyran (2005) are the first to examine whether and to what extent statutory tax incidence affects the performance of efficiency-wage markets and whether Tax 
Liability Side Equivalence $^{2}$ (tax LSE) holds in gift-exchange labor markets. Theory predicts that tax LSE also holds in gift-exchange labor markets as long as participants are only concerned with net wages and profits. Yet, if workers make their effort choices on the basis of the gross wages and consider taxation as exogenous to the gift-exchange relation, tax LSE breaks down. This alternative hypothesis is suggested by a study of Kerschbamer and Kirchsteiger (2000) who show that tax LSE may break down bilateral bargaining environments.

In a one-sided auction environment, Riedl and Tyran (2005) implement two treatments, differing in the sequence of two distinct tax regimes. In one regime the tax is levied on firms (Tax on Firms: ToF) while in the other regime workers are instead obliged to pay the tax (Tax on Workers: ToW). Each regime lasts for 16 trading periods.

The authors find that the gift-exchange relation, that is, effort level increase with wage offers, is unaltered when taxes are introduced. The main result is, however, that tax LSE holds in the gift-exchange labor markets under study. None of the analyzed variables, net wages, worker efforts, and net earnings, significantly differ between regimes, not even in the short run. Average net wages are almost the same in both tax regimes right from the very beginning. Net wages decrease somewhat when the tax is shifted from the firms to the workers, and increase somewhat when firms are taxed but none of these differences are found to be statistically significant. Similarly, workers' earnings as well as firms' profits are not different across nor within treatments, thus clearly supporting tax LSE.

\section{Competition and wage rigidity}

One main idea behind gift-exchange is that, given that the mechanism is at work, firms have no incentive to lower wages because this would lead to low performance of workers and, hence, to low profits. An implication of this is that wages are downwardly rigid.

Following the work of Fehr, Kirchler, Weichbold, and Gächter (1998) the impact of competition on wage rigidity and gift-exchange has later been assessed by Fehr and Falk (1999), who investigate and confirm the existence of wage rigidities in a double auction market, which is considered as particularly competitive (see, e.g., Davis and

\footnotetext{
${ }^{2}$ Tax LSE states that "the statutory incidence (i.e., who legally pays a tax) is irrelevant for economic incidence (i.e., who bears the tax burden)" (Riedl and Tyran (2005)).
} 
Holt 1993). As mentioned above the find that when contracts are complete wages decreases towards workers reservation wage while they stay high when contracts are incomplete and gift-exchange is at work. Importantly, in the incomplete contract environment workers underbid each other but firms are unwilling to accept low wage offers.

Brandts and Charness (2004) analyze whether gift-exchange is affected by the relative number of firms and workers on the market. They implement a market with excess supply of labor (ESL) and a market with excess supply of firms (ESF), with wage formation in a one-sided auction. In addition, they compare sessions with 10 trading periods to a single-period session. They find that wage and effort are positively correlated and that this relation is not affected by competitive pressure. Specifically, wages do not significantly differ across treatments and are generally quite high. The results from the single-period sessions are similar to those in the 10-period sessions. Hence, overall the gift-exchange relation appears to be robust to increased competition on the labor market.

\section{Minimum wage legislation}

The economic and social consequences of minimum wage legislations have received a growing attention over the years. Experimental evidence shows that changes in the level of the minimum wage strongly affect what is perceived by individuals as a fair wage, causing important effects on reservations wages, actual wages, and employment levels.

Brandts and Charness (2004) are the first who studied the effect of a minimum wage on the behavior of firms and workers in a gift-exchange context, with excess supply of workers. They find that the imposition of a minimum wage has a counterproductive effect in terms of effort exerted by workers. Although the relationship between wage and effort remains significantly positive, the impact on effort provision is negative. That is at all wages, effort levels are lower. The average effort chosen when there is a minimum wage is about 50 percent higher than when there is no minimum wage. In addition, the introduction of a minimum wage reduces the likelihood that a high wage is paid. 
Falk, Fehr, and Zehnder (2006) look at the effects of minimum wage in an economy with complete contracts, where workers provide either zero effort, if they reject a wage offer, or automatically provide maximum effort, if they accept a wage offer. They find that, when minimum wages are introduced, workers' endogenous reservation wages increase to above the level of the minimum wage. This suggests that being paid exactly the minimum wage is viewed as unfair by workers. In addition, the introduction and removal of a minimum wage have asymmetric effects. If existing minimum wages are removed reservation wages only marginally decrease and remain substantially above those prevailing before the introduction of the minimum wage.

Owens and Kagel (2010) find partly contrasting results. They observe that that introduction of the minimum wage results in an increase in average wages but also that dropping the minimum wage leads to a decrease in both average wages and average effort. When a minimum wage is introduced the effects on effort levels differ depending on the wage rate. At lower wage rates and, in particular, in the neighborhood of the minimum wage, a reduction in effort is detected, while no systematic effects on effort levels are found for higher wages.

Overall the evidence of the effect of minimum wages on provided effort is mixed. Importantly, however, the surveyed studies show that on the one hand, the minimum wage increases average wages inducing reciprocal workers to exert more effort. On the other hand, the minimum wage may alter subjects' fairness perceptions perhaps due to a reference point effect (Kahneman and Tversky 1979, Abeler, Falk, Goette, and Huffman 2011). Consequently, wages considered fair when there is no minimum wage tend to be perceived as less fair once there is a minimum wage. The net effect of the minimum wage on effort turns out to be ambiguous and depends on the relative size of these two counteracting effects (Fehr, Goette and Zehnder 2009).

\section{Sick pay}

Duersch, Oechssler and Vadovic (2012) experimentally study how sick pay provision and reciprocity interacts in the firm-worker relationship. According to the authors, "contractual provision of sick pay is a perk, a sign of the firm's goodwill, which may be rewarded by the worker with higher performance", but this relation might realize in two different ways. One is referred to as the "gift-exchange hypothesis", and claims that 
workers uniformly reciprocate sick pay; the second is the "selection hypothesis", according to which sick pay could favor the matching between those firms who offer sick pay and those workers who appreciate and reciprocate it.

The authors adapt the standard gift-exchange game, and modify it accordingly to specifically test these hypotheses. In each of 10 periods, employers have to choose from a menu of five contracts each consisting of a wage, $w$, which is paid if the worker shows up for work, and a sick pay, $s$, which is paid otherwise. Workers' lowest effort is equivalent to (pretending to) being sick and not showing up at the workplace. Importantly, the lowest effort may also happen for reasons outside the workers accountability. Firms, however, can only verify if workers show up or not.

Two main treatments are compared. In treatment M (Monopsony) firms and workers are exogenously and anonymously matched in each period and in treatment $\mathrm{S}$ (Selection), firms compete for workers, and are given the possibility of hiring more than one worker.

Gift-exchange results are replicated. Moreover, offering sick pay also increases effort. However, the experimental data also show that offering sick pay contracts is not always the most profitable option for firms. In the $\mathrm{M}$ treatment firms sometimes even suffer losses. Interestingly, on the contrary, when firms have to compete for workers, they earn the highest profit when choosing a contract that offers only a partial sick pay. Firms realize this and most frequently chose the contract consisting of a partial sick pay. Another important result is that sick pay induces self-selection of workers. In both treatments, sick pay contracts attract more reciprocal workers. In conclusion, in the presence of gift-exchange the effectiveness of sick pay is driven by the competition in the labor market.

\section{Deferred compensation}

Huck, Seltzer and Wallace (2011) experimentally test Lazear's (1979) model of deferred compensation and examine the relationship between a firm's wage offer and worker's effort provision in a three-period game. Deferred compensation contract schemes, where workers are underpaid in the early part of their career and overpaid during the later part, are theoretically shown to induce higher effort because future payments within the firm always exceed future payment elsewhere. However, since 
firms can renege on future payments, the optimality of deferred contracts depends on whether an effective commitment mechanism is at work or not. Four treatments are implemented.

In the main treatment, firms can fully commit to future wage offers (FCT). In the FCT, results appear to be mixed on both sides, firms and workers. While deferred compensation is observed not all firms offer the predicted wage pattern and some workers shirk although they are incentivized not to do. In order to better understand that pattern the authors conduct to control treatments. In one of them, firms cannot commit to pay higher wages later but can only make non-binding promises about future payments (NCT). In the other, firms' wage offers are generated by a computer (CFT) in order to control for the effect of outcome inequality. When there is no commitment device, as predicted, worker's effort and efficiency is low. The main reason for this result seems to be that workers do not believe and hence reciprocate to promises of high future wages and actual wages are indeed lower than promised ones. However, there is evidence for gift-exchange but mainly within a period. Therefore, the authors conclude that the best strategy to induce high effort is not to offer a low wage early and promise a high wage later but offer a high wage right at the beginning. In another treatment, firms' past history on wage promises and actual wages is made available to workers, in order to check for reputation effects (RT). The authors find that actually paying high wages to old workers has indeed a reputation effect and reputation may work as a commitment device, although in the experiment reputation is less effective than full exogenously enforced commitment.

\section{Gift exchange, incentive schemes and contract enforcement}

Laboratory gift-exchange experiments show that reciprocity is an effective device to enforce worker effort when contracts are incomplete. In the field, also material incentives are used to mitigate the enforcement problem. Therefore, the question of how explicit performance incentives and gift-exchange interact with each other has been subject of several studies.

Fehr, Gächter and Kirchsteiger (1997) conduct three treatments involving competitive markets with more workers than firms. In each treatment, firms specify a wage, a desired effort level, and a fine imposed if they detect that workers have shirked (that is, 
if they provided less than the specified level of effort). In the no-reciprocity-treatment (NRT) contract terms are exogenously enforced by the experimenter; in the weakreciprocity-treatment (WRT) workers who accept a contract choose an effort level, and a random device determines whether the firms is able to verify shirking (which is then fined at the specified level); the strong-reciprocity-treatment (SRT) has an additional third stage in which firms can also respond reciprocally, by rewarding or punishing workers (at a cost) after they observe actual effort choices.

The results from WRT show that firms' behavior is affected by reciprocity considerations, as the number of generous offers is significantly higher than in the NRT. Nevertheless, although workers engage on average in gift-exchange, shirking is also quite prevalent. In SRT firms demand and succeed in enforcing much higher effort levels than in the WRT. They punish workers who shirk and reward both those who exactly meet the desired effort and those who over-provide effort. This motivates workers to strongly respond to high wages with high efforts. In consequence, this leads to a higher aggregate monetary payoff, meaning that both workers and firms are best off in the SRT.

Fehr and Gächter (2002) examine the possibility that explicit incentives may create a hostile atmosphere of threat and distrust, undermining voluntary contribution and reducing any reciprocity-based extra effort. They conduct a gift-exchange experiment under two treatments, a trust treatment (TT), which resembles a standard gift-exchange game under the one-sided auction trading rules, and an incentive treatment (IT) where firms can punish shirking workers.

Surprisingly, at partly in contrast to the findings in Fehr, Gächter and Kirchsteiger (1997), in TT firms offer, on average, higher wages and demand higher effort levels than in the IT, which results in higher actual average effort. The authors observe that the lower effort levels in IT are not caused by lower wage offers but that low wages are a response to the reduction of the workers' willingness to reciprocate. Further, in terms of efficiency, the data show that the aggregate surplus is lower in the incentive treatment, due to the reduced effort levels. The authors conjecture that the negative incentive effect is due to framing the material inventive as punishment, which workers may perceive as unkind. To test this, an additional bonus treatment (BT) where a shirking worker, instead of paying a fine, does not receive a bonus if caught shirking, is conducted. The 
incentive structure is exactly the same in IT and BT. Nevertheless, large behavioral differences are observed in IT and BT. With the material incentive framed as bonus effort levels are significantly higher than when it is framed as punishment.

Fehr, Klein and Schmidt (2007) compare the performance of three types of contracts. In the incentive contract the principal offers a wage, a required effort level, and a fine paid in case the agent is caught shirking. If the principal invests in a verification technology, agents' effort choices are observed with the exogenous probability $p=1 / 3$. In the trust contract, the principal offers a fixed wage to the agent and asks for high effort in return. Lastly, the bonus contract is similar to the trust contract, except that the principal announces that $\mathrm{s} /$ he might pay a bonus if the agent exerts more effort than it is required, but he is not forced to. The authors conduct a bilateral gift-exchange experiment with two treatments. In the trust-incentive treatment (TI), principals could choose between trust contract and the incentive contract and in the bonus-incentive treatment $(\mathrm{BI})$, all three contracts could be chosen. In TI, it is found that incentive contracts are chosen by most principals and increasingly preferred over time as they perform better from the firm's perspective. Workers' effort levels and principals' payoffs are higher with incentive contracts than with trust contracts. In stark contrast, in the BI treatment bonus contracts are chosen much more often than the incentive contracts and the trust contract is never chosen as now the bonus contract clearly outperforms the incentive contract. What the authors observe, therefore, is that, on the one hand, in TI fairness concerns are not powerful enough to contradict the standard theory prediction that incentive contracts are preferred to trust contracts. On the other hand, when a non-binding promise to pay bonuses is introduced, the results conflict with what standard theory postulates.

In a later paper, Fehr and Schmidt (2007) wonder whether combining a bonus and an incentive contract helps improving efficiency. Principals can choose between a pure bonus contract and a combined contract (CC), which therefore offers both a fine paid in case of detected shirking and the a voluntary bonus. Still, the authors find that the vast majority of principals prefer the pure bonus contract, which also turns out to be more efficient. These results seem to support the idea that, in many cases, explicit negative incentives may crowd out intrinsic motivation, as agents might perceive a fine as a hostile act and the choice of monitoring the agents as a signal of distrust. 
In a recent paper, Eriksson and Villeval (2012) study whether and how respect, defined as "the expression of recognition by an employer to an employee after observing his performance", is used by employers and perceived by employees. They compare two treatments. The first treatment resembles the gift-exchange game in Brown, Falk, and Fehr (2004), where firms can submit either public or private wage offers in a one-sided auction market and build long-term relationships. In the respect treatment a third stage is added, where firms can express their respect towards their workers by sending them a non-monetary reward (a raised thumb) which is costly to them but does not change the workers' payoff. Both treatments are played under three market conditions: one where the number of employers is the same as the number of employees, one with excess supply and one with excess demand in the labor market.

A, perhaps surprising, result is that the majority of employers do not send symbolic rewards. More symbolic rewards are sent when there is competition on the labor market than when it is balanced and they are mainly used to initiate longer-term relationships. Once established its use largely vanishes. Interestingly, receiving rewards induce higher efforts only when the market is balanced. In consequence, the respect treatment leads to higher profits only in that market condition.

Fehr, Kirchsteiger and Riedl (1996) study incentive effects on efforts in different environment. Specifically, they test whether, as the shirking version of the efficiency wage hypothesis predicts (Shapiro and Stiglitz 1984), higher wages and lower effort requirements reduce shirking. In one treatment (EWE) firms with different production technologies offer contracts consisting of a wage, a required effort level, and a penalty levied on the worker in case caught shirking. The results are then compare to a market clearing experiments (MCE), where the incentive to pay efficiency wages is removed by allowing the imposition of a higher penalty. In the EWE it is observed that firms make a rational and selfish use of penalties, meaning that the great majority of the chosen penalties meet the standard theoretical predictions. However, wage offers and demanded effort levels tend to lie below the predicted values, suggesting that firms' choices might be affected by risk aversion. In the MCE the market converges to the predicted values. Most importantly, the authors find support for the efficiency wage hypothesis as an increase in the wage offered reduces the probability of shirking and firms try to pay job 
rents to induce workers not to shirk. Finally, it is shown that the existence of efficiency wages leads to involuntary unemployment.

\subsection{Robustness and extensions of gift-exchange labor markets}

Gift-exchange labor market experiments have been conducted under many environmental conditions. In particular, the strong positive relationship between wage and effort has been confirmed by a large number of papers. There are, however, some experimental conditions where gift-exchange may not be robust against. The experiments summarized in this section propose extensions of the basic gift-exchange game design and the try to assess whether and to what extent changes in the environmental features impact on behavior.

\section{Gift-exchange, multi-worker firms and social comparisons}

The external validity of experimental results gathered in relative simple environments is a challenge for experimental economics in general and for gift-exchange labor market experiments in particular. For instance, the mostly used implementation of giftexchange markets where employment relationships involve one employer and one employee may limit the validity of results for cases where employers can hire more than one worker.

Maximiano, Sloof and Sonnemans (2007) compare a standard one-employer-oneworker (1-1) bilateral gift-exchange game with one in which each firm has four workers (1-4). In the latter case, the firm has to pay the same wage to all workers, who then simultaneously decide how much effort to provide without knowing the effort choices of their co-workers. In both treatments, workers choose, on average, a higher effort level when the offered wage is higher and the difference between treatments is small and statistically not significant. Although, the wage-effort relationship is steeper in the in the 1-1 treatment, overall the wage-effort relation is robust to an increased number of workers within a firm.

The previous paper is mainly concerned with the relationship between agents at different levels in the firm hierarchy. Charness and Kuhn (2007), examine how the horizontal relationship between workers and the observation of each other's wages may affect effort choices. They match two workers with different productivity levels (high 
and low) within one firm. Workers know that their productivity is different from their co-workers', but they do not know the direction of this difference. Firms can offer their workers different wages. The authors also vary, in a within-subjects design, whether wage offers are public (both workers know both wages) or private (workers know only their own wage).

Data show that, when a co-worker' wage is secret, workers' effort choices respond very strongly to their own wage, while no effect of co-workers' wages on effort is found. The more interesting result is that the same holds when workers are informed of their co-workers' wage before choosing their own effort. Hence, workers seem to be mainly concerned with their own wage offer and horizontal comparisons are either not important or wage differences are perceived as justified because of the productivity differences.

Charness and Kuhn's (2007) results are challenged by a recent paper by Gächter and Thöni (2010). They find that, when a worker is paid less than a co-worker, s/he significantly reduces his/her effort relative to a situation where equal wages are paid. It has to be emphasized, however, that in contrast to Gächter and Thöni (2010) workers in Charness and Kuhn (2007) are characterized by different productivity levels, which likely affects effort responses. Gächter and Thöni (2010) broaden this analysis by investigating whether the observed pay comparison effects actually come from wage differences or are instead due to an aversion to intentional wage discrimination. In an additional treatment, a random device chooses workers' wages on behalf of firms. It turns out that disadvantageous wage discrimination does not result anymore in reduced effort levels and, hence, intentionality is the source of reduced efforts in case of unequal wages.

Gächter, Nosenzo and Sefton (2010) go a step further and investigate whether exposure to both pay and effort comparison information influences reciprocal behavior. In a three-person gift-exchange game, the employer chooses a wage, which can be different for different workers; the employees first observe both wages and then choose (sequentially) an effort level. The worker who moves second (Employee 2), hence, also receives information about the co-worker's effort choice.

The authors find that in this setting pay comparisons do not affect effort choices. However, for a given wage combination, a worker's effort depend on the co-worker's 
effort decision. Employee 2 exerts high effort if Employee 1 does so and tends to choose low effort if the co-worker also chooses low effort. Hence, on average reciprocity towards the employer is weakened by exposure to effort comparison information.

Nosenzo (forthcoming) studies pay comparison effects in a gift exchange game where one employer is matched with two symmetric employees, and compares effort choices under three treatments: in the "pay secrecy" treatment the employer chooses the two wages s/he pays to the employees and each employee only knows his/her own wage, in the two "public wages" treatments both wages are known to both employees. The two "public wages" treatments differ in how wages are determined. In one treatment the employer can choose both wages, while in the other one wage is chosen exogenously set by the computer. The data show that information about co-workers' wages can be detrimental for effort provision. In the pay secrecy treatment workers effort levels are higher than in the other two treatments as with public wages employees who are underpaid relative to the co-worker exert less effort than employees in the pay secrecy treatment. Interestingly, this holds even when co-workers' wages are chosen exogenously. Moreover, in the latter case, workers lower their effort provision even if they are overpaid relative to the co-workers.

In Abeler et al. (2010) one principal is matched with two agents, who simultaneously choose effort in the first stage of a gift-exchange game and principals chooses a wage only after having observed the agents effort choices. In one treatment the principal has to pay the same wage to both agents while in a second treatment she can set different wages for the two agents. The authors find that in the equal wage treatments effort levels are significantly lower than when agents are paid individually, suggesting that agents perceive equal wages for unequal performance as unfair. In the individual wage treatment principals seem to anticipate that and pay higher wages to agents who exert higher effort. Moreover, when wages are set equal by the employer, employees who initially work hard tend to reduce effort to the level of their low-performing co-workers. The opposite occurs when workers are paid individually. In that case, those workers who initially exert low effort align with the high-performers.

Siang, Requate and Waichman (2010) also test for horizontal comparisons in a bilateral gift-exchange game, under both random and fixed matching, where workers are 
provided with either quantitative or qualitative information about the average wage in the market. ${ }^{3}$ Overall, it is found that letting players receive any information about average wages has a decreasing effect on both wage and effort in the random matching treatments, and the opposite effect under the fixed matching protocol.

\section{Framing}

The way decision tasks are presented in the laboratory may affect behavior. Charness, Frechette and Kagel (2004) investigate whether providing experiment participants with a comprehensive payoff table has any effect on gift-exchange. They run a standard giftexchange game under two different conditions. In both conditions subjects are given the payoff functions and in one treatment subjects are, in addition, given a complete payoff table reporting firms and workers' payoffs for all combination of wages and effort. Charness, Frechette and Kagel (2004) find that the provision of such table, although unnecessary for the subjects to be able to compute payoffs, does have an impact on their behavior. Still gift-exchange is observed in both treatments but the inclusion of the payoff table significantly decreases wages and effort. Further, with the payoff table the wage-effort relationship seems to become weaker over time, especially towards the end of the experiment suggesting strategic effort choices. The authors propose two main explanations for the lowered gift-exchange but leave the ultimate reason open. On the one hand, working through the table and focusing on it may have led workers somehow to regard their effort choices and firms' wage decisions as not linked to each other. On the other hand, the payoff table might have made the distributional consequences more salient, as firms' marginal benefit resulting from an increased effort decreases as wage increases, which might induce lower effort.

\section{Stake levels}

Fehr, Fischbacher and Tougareva (2002) study the impact of the interaction between competitive labor markets and high stakes on fairness concerns. They conduct two treatments of the gift-exchange market: a normal stake condition and a high stake condition, where in the latter the stake level was ten times higher than in the normal

\footnotetext{
${ }^{3}$ More precisely, workers are informed if the employer offers a wage which is $5 \%$ larger or smaller than the average wage across markets.
} 
stake condition, and (Russian) subjects' earnings amounted on average to up to three monthly incomes.

A comparison of participants' behavior in the two treatments reveals that the introduction of high stakes does not weaken the wage-effort relationship. Wages are above the competitive level and quite similar across conditions and, hence, not affected by stake size. The impact of increased stakes on effort is negligible as well. To rule out the possibility that the reported results might be due to Russian subjects' peculiar characteristics the authors perform two additional experiments under the normal stake condition. One compares Russian to Austrian subjects and the other explores how Russian subjects behave in a complete contract market. The results confirm that Russian subjects behavior is not different from behavior known in the literature. Overall the results indicate that market institutions are more important in shaping behavior than stake size.

\section{Market size}

The issue of how market size might affect behavior in a gift- exchange environment is addressed in a recent paper by Brandts, Gërxhani, Schram, and Ygosse-Battisti (2010). They compare two markets, differing in size. In the small market there are 7 traders (5 workers and 2 firms), while the large market has 21 trading agents (15 workers and 6 firms). In each market, trades occur through two different market institutions: double auctions (DA) or bilateral negotiations (BN). The experiment lasts 30 periods in which during the first ten rounds, subjects trade only through DA. In the successive 20 periods, at the beginning of each period, firms choose whether to enter the DA or privately negotiate with a worker. The worker, in turn, indicates whether or not $\mathrm{s} / \mathrm{he}$ is willing to enter the $\mathrm{BN}$. After that, the game proceeds with wage offers, first, and effort decisions, then.

The authors report that gift-exchange proved to be robust to the variation of the number of traders in the market. In both treatments, effort and wages are positively correlated and wages and efforts in $\mathrm{BN}$ are higher than in DA. In both treatments aggregate surplus is considerably higher in periods 11-30 (when DA and BN coexists in the markets) than in the first 10 periods (with only DA). Hence, the market institution is more important in shaping behavior than the market size. 


\section{Transparency}

In many employment relationships the amount of effort exerted by the workers is not perfectly observable by the employer, a circumstance that is ignored in standard giftexchange experiments. The question arises, then, whether workers would still be reciprocal in a situation where hidden actions are possible and, consequently, whether it is still profitable for firms to offer generous wages.

Irlenbusch and Sliwka (2005) addresses this issue, by investigating how transparency of effort choices affects (the degree of) gift-exchange. In their experiment, a firm's payoff is given by the sum of a worker's effort and a random component. Two treatments are conducted. In the revealed-effort treatment, firms are perfectly informed about both components of their payoff, whereas in the hidden-effort treatment, firms only observe their payoff without any further detail. Their results show that the positive wage-effort relation is present in both treatments, but it is much stronger in the revealed effort treatment. When trying to discern the reasons behind it, the authors find that actual effort levels are quite similar across treatments, but wages in the hidden effort treatment are higher. The hidden effort treatment is also characterized by much more heterogeneity in agents' behavior. It seems that some agents take advantage of the principal not being able to observe their effort while others are willing to exert even more than the efficient effort level in order to signal their willingness to reciprocate.

\section{Subject pool}

Hannan, Kagel and Moser (2002) conducted two experiments with two different U.S. subject pools, MBAs and undergraduate students to explore the effect of work experience. They also compared their behavior to that of Austrian students in Fehr, Gächter, Kirchler, and Weichbold (1998) in order to investigate whether peculiarities of U.S. society (namely, a more individualistic approach to work) leads to different results in terms of gift-exchange. The implemented gift-exchange labor markets consist of onesided auctions and firms were either high productivity or low productivity. When comparing U.S. students, MBAs and Austrian students the authors find that all three subject pools exhibit reciprocal preferences, but that U.S. students are less reciprocal than MBAs and Austrian students. Similarly, MBAs' wage offers of are found to be 
considerably higher than those of U.S. students. In order to explore whether U.S. students weak gift-exchange is due to not being familiar with gift-exchange labor markets the authors conduct another treatment where firms have to submit also a desired effort level. In comparison to the first experiment U.S. students exert more effort, which suggest that different work experiences of undergraduates and MBAs may account for differences in their effort responses.

\section{Gift-exchange in field experiments}

Some recent papers study whether and provide evidence that social preferences identified in the laboratory map into real work environments.

Gneezy and List (2006) hire people to perform two real-effort tasks, one involving work in a library and the other involving door-to-door fund raising. In both cases, the participants know that it is a one-time employment. Two treatments per task are conducted. In both treatments a fixed wage per hour is promised. In the first one the promised wage is paid (noGift) and in the second, after the task has been explained, participants are told that they will be actually paid a higher wage (Gift). Consistent with the laboratory evidence, in the early hours of the task higher wages are reciprocated by higher effort levels, as effort in the Gift treatment is markedly higher than in the noGift treatment. This effect, however, vanishes over time. After a few hours, effort levels in the two treatments are statistically indistinguishable.

Kube, Maréchal, and Puppe (2012) analyze how strongly workers reciprocate monetary and non-monetary gifts with higher productivity in a real effort task. They hire students to enter data. In the benchmark treatment all students are paid an announced wage. In the cash treatment participants receive a monetary gift, while in the bottle treatment they are given a thermos bottle of equivalent monetary value. They also run additional control treatments. In one of them, the bottle's market price is explicitly mentioned, to rule out the possibility that workers might overestimate its market value. In the choice treatment, conducted to elicit preferences for receiving cash or the bottle, subjects can choose between the bottle and the money. Finally, in the origami treatment, run to test whether the time and effort invested in the provision of gifts matter, the firm gives the workers money in the form of an origami. 
The results show that the nature of gifts determines the strength of reciprocal behavior. The cash gift has only a statistically insignificant impact on workers' productivity, while the bottle starkly increases workers' performance and the effect remains large throughout the experiment. This result is closely replicated in the treatment where subjects are informed about the price of the bottle. Further, when workers can choose between gifts, almost all of them opt for the cash gift and workers' output is the same as in the no choice bottle treatment and, thus, higher as in the no choice money treatment. This suggests that time and effort the firm spends for a gift matter for the workers. Intriguingly, the data show that workers reciprocate a money gift of the same value as in the cash treatment but presented in origami form with an output level that is 30 percent higher.

In Kube, Maréchal, and Puppe (forthcoming) workers are hired by a university library to catalog books. In the baseline treatment, workers are paid the announced wage. In two other treatments, workers are informed, right before performing their task, that they would be paid either less or more than announced, respectively. They find that, while unexpected wage cuts severely and persistently reduce productivity, analogous wage increases do not lead to higher output levels. A control treatment, where workers' performance is incentivized with piece rates, shows that productivity levels are much higher than in the baseline, demonstrating that workers in the pay raise treatment would actually be able to produce more.

Hennig-Schmidt, Rockenbach and Sadrieh (2010) hire students for a database updating. Next to the baseline treatment, where all workers are paid the same wage, the authors perform some treatments where workers receive an unexpected pay raise and some others where workers are also informed about the wage increase of a peer group.

Data show that neither increases in the own wage nor information on peer wages seem to affect workers' effort, irrespective of whether the peer group's wage is higher or lower than the own wage. Hence, contrary to most laboratory and other field experiments there seem to be no positive wage-effort relation.

The authors complement the analysis with a real effort lab experiment, where employees either receive a flat wage or are exposed to an unexpected wage increase under two conditions, differing in whether the information about the employer's surplus from work effort is available or not. In the absence of surplus information there seems 
to be no positive relation between wage and effort. However, when surplus information is provided this relation is observed. In fact, the positive wage-effort relation is quite steep and a pay raise is indeed profitable for the employers as the fair wage-effort hypothesis claims. This result suggests that workers' being aware of the employer's surplus maybe crucial for reciprocal inclinations to come into play.

\section{Experimental labor markets in macroeconomics and public finance}

Laboratory experiments can be a valuable research tool for investigating aggregate economic phenomena. In this section we survey some papers that try to assess the impact of taxation on economic performance, mainly focusing on the relation between (labor) taxation and unemployment. In a series of studies, Riedl and Van Winden show the existence of a vicious circle in the interaction between wage taxes and unemployment and suggest that shifting the tax burden from labor to sales or production can alleviate the unemployment-boosting effect. Blumkin, Ruffle, and Ganun (2012) test the response of labor supply to various forms of taxation and argue that shifting taxation from labor to consumption increases labor supply, while Ortona, Ottone, Ponzano, and Scacciati (2008) find the same effect on effort provision coming from destining taxes to insure subjects against risk and to finance public goods.

Riedl and van Winden (2001) are the first to use laboratory experiments to investigate the nexus between labor taxation and unemployment. In particular, they study the effects of a wage tax system to finance unemployment benefits on the performance of an economy, mainly in reaction to tax adjustments to a budget deficit or surplus. The economy under consideration consists of two countries, a small "home" country and a large "foreign" country, where two inputs, capital K and labor L, and two outputs, X and $\mathrm{Y}$, can be traded. In each country, goods $\mathrm{X}$ and $\mathrm{Y}$ are produced in two separate sectors with the help of inputs L and K. These inputs are, respectively, traded on a local labor market (separate in each country) and on an international capital market. Similarly, the market for commodity $\mathrm{X}$ is international, while the market for commodity $\mathrm{Y}$ is local. Consumers derive utility from leisure, the unsold units of labor, and the consumption of $\mathrm{X}$ and $\mathrm{Y}$. They are endowed with some units of labor and capital, and they obtain an unemployment benefit for each unsold unit of their labor endowment. 
The government finances these benefits with the help of a tax on employed labor paid by producers. Two tax regimes are implemented in each country. During the first part of the experimental session, wage taxes are held constant. During the second part, the wage tax rate is adjusted to the previous period's deficit or surplus in the government budget.

Riedl and van Winden (2001) find that, in the constant tax regime, both countries experience a budget deficit in all periods, which does not decrease over time. They also show that, while unemployment levels converge to the equilibrium values, nominal wages are very low in both countries. A thorough analysis of consumers and producers behavior shows that the former supply too much labor at given prices, while the latter have a tendency to employ too few labor units. This supports the so-called riskcompensated price-mechanism hypothesis, which was first detected in pure commodity markets by Noussair, Plott, and Riezman (1995). Normally, when producers make their input decisions, the market conditions prevailing at the time consumers buy their products are unknown, meaning that they face uncertainty about the revenues they can make by selling those products. Given this price uncertainty, risk-averse producers demand less labor than predicted in equilibrium. Producers and consumers combined behavior lead to an upward trend of unemployment rates and drive nominal wages down, which explains the observed budget deficit. In the dynamic tax regime, an initial considerable increase in the tax rates is observed as the previous periods' budget is not balanced. Increased taxes help to decrease the budget deficit over time. In comes, however, at the cost of strong negative effects on the performance of the economy as a whole. In both countries unemployment rates increase and real GDP sharply decreases.

In Riedl and van Winden (2007), the authors use the same setup to compare a closed with an international economy. Overall the data confirm the earlier results. When the tax rate is constant, in all economies a budget deficit occurs already in early periods. The same excess supply of labor is observed, which is accompanied by producers' reluctance to buy inputs and a downward trend of wages. Together this accounts for the observed budget deficits. Once the dynamic tax regime is introduced, in all economies the deficit becomes smaller due to higher tax rates but the unemployment level increases, an effect that is due to the low employment of factors (because of price uncertainty) and exacerbated for labor by the wage tax. 
These findings show, once again, that there exists a vicious circle in the interaction between wage tax and unemployment, and suggests that shifting taxation from labor to consumption or sales might turn out to be beneficial for both production and employment levels. To explore this, Riedl and Van Winden (2012) use the same economic environment and introduce a sales-tax-cum-labor-subsidy (STLS) system, which is compared to a pure wage tax (WT) system. Two treatments are implemented. In the baseline treatment, in both the home country and the foreign country unemployment benefits are financed with a wage tax. In the alternative treatment, in the home country the WT system is substituted by the STLS system while the WT system prevails in the foreign country. Next to shifting the tax from labor to sales, in the STLS system producers also receive a subsidy equal to the unemployment benefit for each unit of labor they employ. Again, a constant tax regime is followed by a regime where the tax rate adjusts to previous periods' budgets.

In the constant tax regime, (almost) all quantities and prices, as well as economic performance indicators, such as unemployment rate and real GDP, weakly converge to the theoretically predicted equilibrium values. In the small country, the unemployment rate is initially higher when the STLS-system is effective, but it tends to decrease over time, despite high sales taxes. On the contrary, such development is not observed under the WT-system. Moreover, the declining unemployment under the STLS-system seems to be associated with an increase in the budget surplus of the small country, while wage taxes are systematically accompanied by budget deficits. A similar pattern is observed for the real GDP. At the end of the constant tax regime, the economies under the WTsystem face budget deficits, while budget surpluses are generated in the small country under the STLS-system. As a consequence, the transition to the variable tax regime is characterized by an increase in the tax rates in the former case, and by a decrease in the latter case. The increasing tax rates in the WT-system lead to increasing unemployment and a decrease in real GDP, while at the same time the burden from the budget deficit merely weakens. In stark contrast, in the alternative tax system, the initial decline in sales tax rates reduces unemployment and boosts real GDP. In addition, the budget immediately balances and stabilizes over time. Overall, Riedl and van Winden's (2012) results show that the STLS-system leads to a significantly better economic performance compared to a wage tax system. These differential results are mainly driven by 
producers' reluctance to incur upfront costs when they are uncertain about output prices. Importantly, producers seem to perceive uncertainty differently under the two tax systems because receiving a labor subsidy and paying taxes according to sales revenues basically gives producers the opportunity to share their risk with the government.

Blumkin, Ruffle and Ganun (2012) experimentally test the equivalence between consumption and wage taxes. They implement two tax treatments, one with a consumption tax and another with an equivalent wage tax, where subjects have to decide how to allocate their time between labor (a real-effort task) and leisure. Subjects receive an income according to their performance at the real effort-task, which they are then asked to allocate between two consumption goods. They also receive a payment for each unit of leisure consumed. The experiment consists of three parts: the first two are meant to measure and control for subjects' productivity and pre-tax labor-leisure preferences, respectively. Finally, in the third part either a labor-income tax (IT) or a consumption tax (CT), depending on the treatment, is introduced.

Although theoretically equivalent, worker-consumers may work more and consume less leisure in presence of a consumption tax because of money illusion, meaning that individuals tend to think in nominal and not in real terms (for empirical evidence on money illusion see, e.g, Fehr and Tyran 2001). In that case labor-income taxes and consumption taxes may be perceived differently when the labor supply decision has to be made. The impact of the labor-income tax is evident when subjects are asked to make their decision while the effect of the consumption tax is not. In consequence, subjects would work more in the CT treatment than in the IT treatment. This is indeed what authors find. Specifically, those worker-consumers who reduce their labor supply when a tax is introduced, reduce it significantly more when there in IT. In line with Riedl and van Winden (2012), this result suggests that shifting taxation from labor to consumption might potentially lead to welfare improvements, with higher individuals' utility and unchanged government tax revenues. (A related salience effect of taxation is also found for consumer goods by Chetty, Looney, and Kroft 2009)

Ortona et al. (2008) investigate the relation between labor supply and taxation, but assume that tax revenues are used for the production of public goods. More specifically, they run a real effort experiment and compare the labor supply in two states of the world. In a so-called state of nature (SN) there is a certain risk to lose part of the earned 
income and there are no taxes, insurance and public goods, and a welfare state (WS), where there is the same risk partially insured, a proportional income tax and a public good. Subjects are requested to state both how many tasks they want to perform under each contract and their preference for a contract, before they are randomly assigned to one of the two contracts and actually carry out the given task. Their main result is that subjects work more under WS than under SN, which suggests that the fact that the returns from taxes are used to protect subjects against risk and provide public goods does not reduce, but possibly increases, labor supply.

\section{Conclusions}

Laboratory experiments have entered labor economics and the generated results have significantly increased our knowledge on a variety of aspects. In this paper we have surveyed part of this literature and concentrated on two main areas. The first part has been devoted to the behavioral consequences of contractual incompleteness in a giftexchange environment and in the second part more macroeconomics oriented experiments have been presented, which mainly focus on the interaction between taxation and labor market performance.

Many employment relations are often contractually incomplete in terms of effort that workers are required to exert. In such contexts, workers' reciprocal inclinations play an important role in determining the overall surplus and profit of the firm. Laboratory experiments provide abundant evidence that a sizable share of people exhibits fairness concerns and shows that reciprocity often can substitute for the absence of a formal contract enforcement device. It is now a well-established result that a positive relationship between the wages offered by firms and the effort exerted by workers exists, and that employers are actually willing to offer wages higher than the prevailing minimum to elicit higher effort. The prevalence of reciprocity in the form of giftexchange has been shown in one-shot interactions as well as in repeated interactions.

The importance of gift-exchange in employer-employee relations has several policy implications. For instance, it has been shown that gift-exchange wages turn out to be downwardly rigid speaking to Bewley's (1999) book title "why recessions don't fall during recessions." A consequence is that the introduction of a minimum wage may have unintended effects as it has been shown that a minimum wage may change 
workers' reference point of a fair wage and, hence, affect their effort provision. Further, the interaction between reciprocal inclinations and various incentive schemes has to be carefully taken into account as it does not necessarily hold that explicit incentives will have unambiguous positive effects on effort. In fact, explicit incentives may crowd out intrinsic motivation as agents may consider a fine or a punishment as a hostile act or being monitored as a signal of distrust, which may induce lower effort levels.

The positive relationship between wage and effort has been confirmed under a broad range of conditions. Among other, studies have also shown that MBAs are much more reciprocal than undergraduates. Nevertheless, the generalizability of gift-exchange results to more complex field environments has sometimes been questioned. Recently, scholars have been started to study situations where employers can hire more than one worker, focusing in particular on the interplay between reciprocity and wage and effort comparisons. Overall also in these studies gift-exchange is observed. However, the strength of it may hinge on details of the environment. For instance, effort comparisons seem to have a stronger impact on workers' effort choices than wage comparisons.

Also only recently field experiments have been used to investigate gift-exchange. The empirical results of the few studies are mixed in that some find a positive wage-effort relationship while others don't. In the field, it seems that a wage cut has stronger effects than a wage increase and non-monetary gifts have a stronger effect than a purely financial gift. An important open question is also the longevity of gift-exchange. As field experiments are almost always less controlled than laboratory set-ups it is not clear yet what precisely is behind the larger variation in outcomes in field settings. It seems clear that much more research is required to filter out the institutional details that enhance or hamper gift-exchange in work relationships.

The second part of this survey has been dedicated to the relatively small but important set of experiments aimed at assessing the impact of fiscal policies on economic performance, while taking a close look at the evolution of the labor market. There results show the existence of a vicious circle in the interaction between wage taxes and unemployment because increasing labor taxes to balance budget deficits strongly and negatively affect overall economic performance. It is suggested that shifting the tax burden from labor to sales or production might alleviate this effect. This research also explores conditions under which imposing a tax might foster effort 
provision. For instance, it is found that shifting taxation from labor to consumption increases labor supply. Overall, the number of laboratory experiments explicitly aiming at labor market questions traditionally belonging to macroeconomics and public finance are still very rare. Interestingly, it is precisely these more traditional areas in economics that lately have been criticized by a skeptical public opinion. More experimental research in the laboratory (as well as the field) investigating such important questions as the perception of salience of different forms of labor taxation and the behavioral equivalence of theoretically equivalent policy interventions could help could be very informative for these fields too. Moreover, most of the experimental labor research takes place in a partial equilibrium setting where labor relationships and labor markets are assumed to operate on an isolated island. This has been an important and useful restriction in order to generate first clean results. Now the evidence and our knowledge has accumulated so much that time seems ripe to make the step out of the partial world and investigate more general market interactions in labor relations as it already has been done in international trade and other interactive markets experiments (Lei and Noussair 2007, Noussair et al. 1995, 2007).

\section{References}

Abeler, J., Altmann, S., Kube, S. and Wibral, M. (2010). Gift Exchange and Workers' Fairness Concerns: When Equality is Unfair, Journal of the European Economic Association, 8: 1299-1324.

Abeler, J., Falk, A., Goette, L. and Huffman, D. (2011). Reference Points and Effort Provision, American Economic Review, 101: 470-492.

Akerlof, G.A. (1982). Labor Contracts as Partial Gift Exchange, Quarterly Journal of Economics, 97: 543-569.

Akerlof, G.A. and Yellen, J.L. (1988). Fairness and Unemployment, American Economic Review 78: 44-49.

Akerlof, G.A. and Yellen, J.L. (1990). The Fair Wage-Effort Hypothesis and Unemployment, Quarterly Journal of Economics, 105: 255-283.

Bardsley, N. (2008). Dictator game giving: altruism or artefact?, Experimental Economics, 11: 122-133.

Bewley, T. F. (1999). Why Wages Don't Fall During a Recession, Harvard University Press: Cambridge, MA.

Blumkin, T., Ruffle, B. and Ganun, Y. (2012). Are income and consumption taxes ever really equivalent? Evidence from a real-effort experiment with real goods, European Economic Review, 56: 1200-1219. 
Bolton, G. and Ockenfels, A. (2000). ERC: A theory of equity, reciprocity and competition, American Economic Review, 90: 166-193.

Brandts, J. and Charness, G. (2004). Do Labour Market Conditions Affect Gift Exchange? Some Experimental Evidence, Economic Journal, 114: 684-708.

Brandts, J., Gërxhani, K., Schram, A. and Ygosse-Battisti, J. (2010). Size doesn't matter! Gift exchange in experimental labor markets, Journal of Economic Behavior \& Organization, 76: 544-548.

Brown M., Falk, A. and Fehr, E. (2004). Relational Contracts and the Nature of Market Interactions, Econometrica, 72: 747-780.

Charness, G. (2004), Attribution and Reciprocity in an Experimental Labor Market, Journal of Labor Economics, 22: 665-688.

Charness, G., Frechette, G. and Kagel, J. (2004). How Robust is Laboratory Gift Exchange?, Experimental Economics, 7: 189-205.

Charness, G. and Kuhn, P. (2007). Does Pay Inequality Affect Worker Effort? Experimental Evidence, Journal of Labor Economics, 25: 693-723.

Charness, G. and Kuhn, P. (2011). Lab Labor: What Can Labor Economists Learn from the Lab? in Handbook of Labor Economics, Elsevier B.V., 4A, 229-330.

Chetty, R., Looney, A. and Kroft, K. (2009). Salience and Taxation: Theory and Evidence, American Economic Review, 99: 1145-1177.

Davis, D. D. and Holt, C. A. (1993). Experimental economics, Princeton University Press.

Duersch, P., Oechssler, J. and Vadovic, R. (2012). Sick pay provision in experimental labor markets, European Economic Review, 56: 1-19.

Dufwenberg, M. and Kirchsteiger, G. (2004). A Theory of Sequential Reciprocity, Games and Economic Behavior, 47: 268-98.

Eriksson, T. and Villeval, M. C. (2012). Respect and relational contracts, Journal of Economic Behavior \& Organization, 81: 286-298.

Falk, A., Fehr, E. and Zehnder, C. (2006). Fairness Perceptions and Reservation Wages. The Behavioral Effects of Minimum Wage Laws, The Quarterly Journal of Economics, 121: 1347-1381.

Falk, A. and Fischbacher, U. (2006). A theory of reciprocity, Games and Economic Behavior, 54: 293-315.

Fehr, E. and Falk, A. (1999). Wage Rigidity in a Competitive Incomplete Contract Market, Journal of Political Economy, 107: 106-134.

Fehr, E., Fischbacher, U. and Tougareva, E. (2002). Do High Stakes and Competition Undermine Fairness? Evidence from Russia, IEW - Working Papers No. iewwp120.

Fehr, E. and Gächter, S. (2002). Do Incentive Contracts Crowd out Voluntary Cooperation? IEW - Working Papers No. iewwp034.

Fehr, E., Gächter, S. and Kirchsteiger, G. (1997). Reciprocity As a Contract Enforcement Device: Experimental Evidence, Econometrica, 65: 833-860.

Fehr, E., Goette, L. and Zehnder, C. (2009). A Behavioral Account of the Labor Market: The Role of Fairness Concerns, Annual Review of Economics, 1: 355-384. 
Fehr, E., Kirchler, E., Weichbold, A. and Gächter, S. (1998). When Social Norms Overpower Competition: Gift Exchange in Experimental Labor Markets, Journal of Labor Economics, 16: 324-351.

Fehr, E., Kirchsteiger, G. and Riedl, A. (1993). Does Fairness Prevent Market Clearing? An Experimental Investigation, Quarterly Journal of Economics, 108: 437-460.

Fehr, E., Kirchsteiger, G. and Riedl, A. (1996). Involuntary Unemployment and Noncompensating Wage Differentials in an Experimental Labour Market, Economic Journal, 106: 106-121.

Fehr, E., Kirchsteiger, G. and Riedl, A. (1998). Gift Exchange and Reciprocity in Competitive Experimental Markets, European Economic Review, 42: 1-34.

Fehr, E., Klein, A. and Schmidt, K. (2007). Fairness and Contract Design, Econometrica, 75: 121-154.

Fehr, E. and Schmidt, K.M. (1999). A Theory of Fairness, Competition and Cooperation, Quarterly Journal of Economics, 114: 817-868.

Fehr, E. and Schmidt, K.M. (2007). Adding a Stick to the Carrot? The Interaction of Bonuses and Fines, American Economic Review, 97: 177-181.

Fehr, E. \& Tyran, J.-R. (2001). Does Money Illusion Matter?, American Economic Review, 91: 1239-1262.

Gächter, S., Nosenzo, D. and Sefton, M. (forthcoming). The Impact of Social Comparisons on Reciprocity, Journal of the European Economic Association.

Gächter, S. and Thöni, C. (2010). Social comparison and performance: Experimental evidence on the fair wage-effort hypothesis, Journal of Economic Behavior \& Organization, 76: 531-543.

Gneezy, U. and List, J.A. (2006). Putting Behavioral Economics to Work: Testing for Gift Exchange in Labor Markets Using Field Experiments, Econometrica, 74: 13651384.

Hannan, R., Kagel, J. and Moser, D. (2002). Partial Gift Exchange in an Experimental Labor Market: Impact of Subject Population Differences, Productivity Differences, and Effort Requests on Behavior, Journal of Labor Economics, 20: 923-951.

Hennig-Schmidt, H., Rockenbach, B. and Sadrieh, K. (2010). In Search of Workers' Real Effort Reciprocity - A Field and a Laboratory Experiment, Journal of the European Economic Association, 8: 817-837.

Huck, S., Seltzer, A. and Wallace, B. (2011). Deferred Compensation in Multiperiod Labor Contracts: An Experimental Test of Lazear's Model, American Economic Review, 101: 819-843.

Irlenbusch, B. and Sliwka, D. (2005). Transparency and reciprocal behavior in employment relations, Journal of Economic Behavior \& Organization, 56: 383-403.

Kagel , J.H. and Owens, M.F. (2010). Minimum Wage Restrictions and Employee Fffort in Incomplete Labor Markets: An Experimental Investigation, Journal of Economic Behavior \& Organization, 73: 317-326.

Kahneman, D. \& Tversky, A. (1979). Prospect Theory: An Analysis of Decision under Risk, Econometrica, 47: 263-292. 
Kerschbamer, R. \& Kirchsteiger, G. (2000). Theoretically robust but empirically invalid? An experimental investigation into tax equivalence, Economic Theory, 16: 719734.

Kube, S., Maréchal, M.A. and Puppe, C. (2012). The currency of reciprocity - Giftexchange in the workplace, American Economic Review, 102: 1644-1662.

Kube, S., Maréchal, M.A. and Puppe, C. (forthcoming). Do Wage Cuts Damage Work Morale? Evidence from a Natural Field Experiment, Journal of the European Economic Association .

Lei, V. \& Noussair, C. N. (2007). Equilibrium selection in an experimental macroeconomy. Southern Economic Journal, 74, 2, 448-482.

Levine, D. K. (1998). Modeling altruism and spitefulness in experiments, Review of Economic Dynamics, 1: 593-622.

List, J. A. (2007). On the Interpretation of Giving in Dictator Games, Journal of Political Economy, 115: 482-493.

Maximiano, S., Sloof, R. and Sonnemans, J. (2007). Gift Exchange in a Multi-worker Firm, Economic Journal, 117: 1025-1050.

Maximiano, S., Sloof, R. and Sonnemans, J. (forthcoming). Gift Exchange and the Separation of Ownership and Control, Games and Economic Behavior, 77: 41-60.

Nosenzo, D. (forthcoming). Pay secrecy and effort provision, Economic Inquiry.

Noussair, C. N.; Plott, C. \& Riezman, R. (1995). An experimental investigation of the patterns of international trade, American Economic Review, 85: 462-491.

Noussair, C. N.; Plott, C. \& Riezman, R. (2007). Production, trade and exchange rates in large experimental economies, European Economic Review, 51, 46-76

Ortona, G., Ottone, S., Ponzano, F. and Scacciati, F. (2008). Labour supply in presence of taxation financing public services. An experimental approach, Journal of Economic Psychology, 29: 619-631.

Pereira, P., Silva, N. and Silva, J. (2006). Positive and negative reciprocity in the labor market, Journal of Economic Behavior \& Organization, 59: 406-422.

Rabin, M. (1993). Incorporating Fairness into Game Theory and Economics, American Economic Review, 83: 1281-1302.

Riedl, A. and Tyran, J. (2005). Tax liability side equivalence in gift-exchange labor markets, Journal of Public Economics, 89: 2369-2382.

Riedl, A. and Van Winden, F. (2001). Does the Wage Tax System Cause Budget Deficits? A Macro-economic Experiment, Public Choice, 109: 371-394.

Riedl, A. and Van Winden, F. (2007). An experimental investigation of wage taxation and unemployment in closed and open economies, European Economic Review, 51: 871-900.

Riedl, A. and Van Winden, F. (2012). Input versus output taxation in an experimental international economy, European Economic Review, 56: 216-232.

Shapiro, C. and Stiglitz, J. E. (1984). Equilibrium Unemployment as a Worker Discipline Device, American Economic Review, 74: 433-444. 
Siang, C.K., Requate, T. and Waichman, I. (2011). On the Role of Social Wage Comparisons in Gift-Exchange Experiments, Economic Letters, 112: 75-78. 